\title{
O STOSOWANIU NARZĘDZI I STRUKTUR FORMALNYCH W FILOZOFII. ONTOLOGIA FORMALNA. ONTOLOGIA TOPOLOGICZNA
}

\begin{abstract}
Abstrakt. Za Arystotelesem logika postrzegana jest jako narzędzie filozofii. Po blisko 2 i pół tysiąca lat dostrzegamy, że nie tylko logika, ale także różne formalne narzędzia i struktury są narzędziami namysłu filozoficznego - i również - naukowego. Zwolennikiem takiego postrzegania sprawy był Jan F. Drewnowski. Narzędzia, o których mówię w tytule, to różnego rodzaju techniki i reguły wypracowane w naukach formalnych. Zaliczyć do nich możemy np. regułę modus ponens czy technikę dowodu rozgałęzionego. Z kolei przez strukturę formalną rozumiem pewien obiekt formalny np. algebrę Boole’a albo przestrzeń topologiczną, które pozwalają modelować przedmioty różnych dziedzin naukowych, w tym filozofii.

W niniejszym artykule zarysuję główne idee Drewnowskiego (i tzw. Koła Krakowskiego na temat konieczności stosowania współczesnych jemu dokonań logicznych i matematycznych oraz pokażę, w jaki sposób ontologię Wittgensteina można modelować w strukturach krat (por. Wolniewicz) i w jaki sposób przestrzeń topologiczna pozwala na analizę tak różnych pojęć filozoficznych jak możliwy świat czy monada. Przykłady te posłużą do argumentacji za prawdziwością metodologicznych tez Drewnowskiego, że (1) stosowanie logiki symbolicznej (oraz różnych struktur formalnych) służy uściślaniu dowolnych dziedzin wiedzy (w tym filozofii) i - jak sądzę - (2) nie narusza bogactwa treści właściwych danej dziedzinie.
\end{abstract}

Słowa kluczowe: narzędzia i metody formalne, kraty, przestrzenie topologiczne, izomorfizm, homeomorfizm, Drewnowski, filozoficzny program Koła Krakowskiego, ontologia formalna, ontologia topologiczna

1. Filozoficzny program Drewnowskiego. Filozoficzny program Koła Krakowskiego. 2. Formalizm w ontologii. Podejście algebraiczne, podejście topologiczne. 2.1. Preliminaria formalne.

2.2. Formalne podejście do programu Koła Krakowskiego w ujęciu Drewnowskiego. 


\section{FILOZOFICZNY PROGRAM DREWNOWSKIEGO. FILOZOFICZNY PROGRAM KOŁA KRAKOWSKIEGO}

Swój program filozoficzny Jan F. Drewnowski zawarł w sposób prawdopodobnie najpełniejszy w Zarysie programu filozoficznego ${ }^{1}$. W niniejszym artykule skupię się jednak na pracy z 1958 r.: Uprogu nowoczesnej syntezy filozoficznej. Zarys opublikowany był w Przegladzie Filozoficznym w roku 1934, natomiast U progu nowoczesnej syntezy filozoficznej w ZNAK-u w roku $1958^{2}$. Niech więc wolno mi przyjąć hipotezę, że ta druga praca jest bardziej dojrzalsza i prezentuje w sposób bardziej precyzyjny zamysły Drewnowskiego.

Drewnowski w siedmiu punktach przedstawia główne idee programu, który powstał w kręgu takich filozofów i logików jak ks. Jan Salamucha, o. Józef M. Bocheński, Bolesław Sobociński i - z udziałem głównego bohatera niniejszego artykułu tj. Drewnowskiego. Krąg tych osób nazwano po II wojnie światowej Kołem Krakowskim $^{3}$. Nie będę podawał wszystkich punktów, na które zwraca uwage Drewnowski (i które charakteryzują wg Drewnowskiego program Koła), a skupię się na punktach 1, 2, 3 i 5, które zdają się być najważniejsze $z$ punktu widzenia stosowania narzędzi formalnych w filozofii. Jednocześnie każdy z tych punktów podsumujemy krótkim komentarzem.

W punkcie 1 czytamy: „1. Jedna z pierwszych spraw - to uporządkowanie takich pojęć, jak niewyobrażalny, niezrozumiały, niepojęty, bezsensowny, sprzeczny, niedorzeczny itp. Nie możemy np. wyobrazić sobie więcej niż trzech prostych wzajemnie do siebie prostopadłych w jednym punkcie przestrzeni: mówimy, że przestrzeń jest

1 J.F. Drewnowski, Filozofia i precyzja. Zarys programu filozoficznego i inne, red. S. Majdański, S. Zalewski, Lublin 1996.

2 J.F. Drewnowski, U progu nowoczesnej syntezy filozoficznej, ZNAK 10(1958)53, 1228-1303.

3 Szczegóły powstawania tej grupy i ich działalność naukową przedstawia praca Z. Wolak, Naukowa filozofia Koła Krakowskiego, Zagadnienia Filozoficzne w Nauce 36(2005), 97-122. 
trójwymiarowa. Cztery lub więcej wzajemnie do siebie prostopadłych $\mathrm{w}$ jednym punkcie to $\mathrm{w}$ przestrzeni trójwymiarowej - n i e d or z e c z no ść. Ale w przestrzeni więcej niż trójwymiarowej, której w yobra zi ć sobie nie możemy, ale którą możemy opisywać za pomocą symboli matematycznych tak samo poprawnie, jak przestrzeń trójwymiarową - w takiej przestrzeni więcej niż trzy prostopadłe w jednym punkcie stają się zupełnie z ro zu mi a łe, choć pozostają nadal $\mathrm{n}$ i e w yo bra ża $1 \mathrm{n}$ e. Podobnie matematyk rozumuje w sposób zupełnie zrozumiały za pomocą symboli różnych zbiorów nieskończonych. Zbiorów tych w swej nieskończonej złożoności nawet myślą ogarnąć nie możemy, są niepojęte, a jednak twierdzenia o nich, wyrażane za pomocą odpowiednich symboli, są zupełnie zrozumiałe"4.

Komentarz. Pojęcia, które Drewnowski proponuje uporządkować ubierzmy w pary: wyobrażalny - niewyobrażalny, zrozumiały - niezrozumiały, pojęty - niepojęty, sensowny - bezsensowny, sprzeczny i niesprzeczny, i wreszcie dorzeczny i niedorzeczny. Traktuję te terminy (pojęcia) jako terminy metodologiczne. Mają bowiem one wyjaśnić nam, co to znaczy w nauce, filozofii czy teologii, gdy posługujemy się tymi terminami. Są to terminy (i pojęcia) kluczowe - nie zawsze metodologowie (i filozofowie) je tłumaczą, przyjmując, że są to terminy pierwotne lub dobrze już zdefiniowane. Tak jednak nie jest: terminy, uważane za pierwotne, powinny być wyjaśnione przez precyzyjny kontekst, w którym są używane (por. termin „leży między" i aksjomatykę nadaną np. przez Grzegorczyka). Definicje zaś często są pomijane.

Omówienie dokładnego znaczenia każdego terminu, wskazanego $\mathrm{w}$ powyższych parach, jest zadaniem na oddzielną pracę. Tu chcę wyjaśnić tylko niektóre intuicje, które przyświecały prawdopodobnie Drewnowskiemu.

4 J.F. Drewnowski, U progu nowoczesnej syntezy filozoficznej, art. cyt, 169. 
Rozważmy, dla przykładu, problem takich pojęć, które są niewyobrażalne a jednak zrozumiałe. Wydaje się, że trudno jest mówić o odległości dwóch punktów w przestrzeni więcej niż trójwymiarowej. Matematyk czyni to jednak z łatwością i - rzeczywiście w sposób zrozumiały. Znany ze szkoły wzór na odległość (d) dwóch punktów $A$ i $B$ (w Euklidesowej przestrzeni dwuwymiarowej):

$$
d(A, B)=\sqrt{\left(x_{2}-x_{1}\right)^{2}+\left(y_{2}-y_{1}\right)^{2}},
$$

gdzie punkt $A$ ma współrzędne $\left(x_{1}, y_{1}\right)$ natomiast $\mathrm{B}$ współrzędne $\left(x_{2}, y_{2}\right)$,

daje się łatwo przekształcić na odległość dwóch punktów $A, B$ w przestrzeni czterowymiarowej. Otrzymujemy wówczas:

$$
d(A, B)=\sqrt{\left(x_{2}-x_{1}\right)^{2}+\left(y_{2}-y_{1}\right)^{2}+\left(z_{2}-z_{1}\right)^{2}+\left(v_{2}-v_{1}\right)^{2}},
$$

gdzie tym razem współrzędne punktów $A$ i $B$ to odpowiednio: $\left(x_{1}, y_{1}, z_{1}, v_{1}\right)$ i $\left(x_{2}, y_{2}, z_{2}, v_{2}\right)$.

Podobnie łatwo zrozumieć cztery proste wzajemnie do siebie prostopadłe (choć, jak wskazuje Drewnowski, trudno to sobie wyobrazić). Podajmy więc stosowny przykład. W przestrzeni dwuwymiarowej dwa wektory o współrzędnych $[1,0]$ i $[0,1]$ są prostopadłe. Jeśli więc rozważymy dowolną liczbę rzeczywistą tj. $a \in \mathfrak{R}$, to $a \bullet[1,0](\bullet$ jest tu mnożeniem liczby przez wektor) daje nam nowy wektor, w tym przypadku $[a, 0]$. Zbiór wszystkich punktów, które są końcem wektora $(0,0)+[a, 0]$, gdzie $(0,0)$ jest punktem, dla $a \in \mathfrak{R}$, daje nam prostą. Podobnie zbiór wszystkich punktów, które są końcem wektora $(0,0)$ + $[0, a]$, gdzie $(0,0)$ jest punktem, dla $a \in \mathfrak{R}$, daje nam prostą. Obie te proste są prostopadłe w przestrzeni dwuwymiarowej (co jest znanym faktem z geometrii analitycznej wykładanej w szkole).

Analogicznie do przykładu $z$ odległością możemy teraz rozważyć przestrzeń czterowymiarową, punkt $(0,0,0,0)$ oraz wektory $a=[a, 0,0,0], b=[0, b, 0,0], c=[0,0, c, 0], d=[0,0,0, d]$ i zbiory punktów, które mają postać: $(0,0,0,0)+[a, 0,0,0],(0,0,0,0)+$ $[0, b, 0,0],(0,0,0,0)+[0,0, c, 0],(0,0,0,0)+[0,0,0, d]$. Okazuje 
się, że wszystkie te zbiory (dla $a, b, c, d \in \Re$ ) są prostymi wzajemnie do siebie prostopadłymi. To, co niewyobrażalne, staje się w pełni zrozumiałe w języku matematyki. Dlaczego? Wystarczy zauważyć, że iloczyn skalarny $\langle v, w\rangle$ dowolnych dwóch wektorów $v$ i $w$ (które "generują" odpowiednie proste) rozważanych powyżej jest równy 0 , a to oznacza, że wektory takie są wzajemnie do siebie prostopadłe (istotnie, np. $\langle a, c\rangle=a \cdot 0+0 \cdot 0+0 \cdot c+0 \cdot 0=0$ ).

„2. Druga grupa pojęć do uporządkowania to takie, jak: niematerialny, duchowy, idealny, nadprzyrodzony itp. Wbrew bardzo rozpowszechnionemu mniemaniu sprawy niematerialne nie są jakimiś wyabstrahowanymi elementami zjawisk materialnych, nie są w nich jakoś zawarte, lecz odwrotnie - »ogarniająu świat materialny »z zewnątrz«: są jakby »wielowymiarowe«, a w nich są zawarte trójwymiarowe ciała materialne. Nie - dusza jest zawarta w ciele, lecz - ciało jest »ogarnięte« przez duszę, nie - treść myśli zawarta jest w głowie, lecz - głowa jest »ogarnięta« przez tę treść. Już u św. Tomasza czytamy wyraźnie: »substantia incorporeasuavirtutecontingens rem corpoream, continetipsam, et non continetur ab ea. Animaenimest in corporautcontinens, et non utcontenta (I, q. 52, a. 1), co znaczy mniej więcej tyle, że: przy oddziaływaniu czegoś niematerialnego na rzecz materialną to coś niematerialnego zawiera tę rzecz, lecz nie jest w niej zawarte. Dusza bowiem w ciele, jako zawierająca je, nie - jako zawarta w nim"5.

Komentarz. W tym fragmencie pojawiają się już określenia filozoficzne oraz metodologiczne określenia teologiczno-filozoficzne: nadprzyrodzony, stosowane między innymi przez św. Tomasza. W tle znów postrzegamy możliwe pary: materialny - niematerialny, duchowy - i materialny (albo zwierzęcy, albo - najprościej - nie-duchowy), idealny - i realny (ale nie tylko), nadprzyrodzony i przyrodzony (naturalny), i być może jeszcze inne pary. W ontologii pojęcia te bywały i nadal bywają różnie rozumiane. Interesujące jest jednak

5 Tamże, 169. 
to, że Drewnowski proponuje, by sens niniejszych terminów i kryjące się za nimi pojęcia wydobyć przez odwrócenie sposobu swojego podejścia o 180 stopni: to nie materialne ciało zawiera duszę, ale odwrotnie - dusza (wielowymiarowa) zawiera ciało, to nie myśl tkwi w głowie, ale głowa jest „ogarnięta” przez treść myśli, która została ujęta przez umysł. Czy te - metaforyczne jednak - ujęcia można ściśle interpretować? Analogia: trójwymiarowe ciało i wielowymiarowa dusza sugeruje pewne intuicje geometryczne. Zwykłe równanie $x=1$ opisuje (w geometrii analitycznej) punkt, gdy rozważania ograniczamy do prostej, prostą, gdy rozważania rozszerzymy na płaszczyznę, następnie opisuje płaszczyznę w przestrzeni trójwymiarowej i pewną przestrzeń trójwymiarową w przestrzeni czterowymiarowej. Postępując dalej, tracimy wyobrażenie tworu geometrycznego opisanego powyższym równaniem, choć w pewien sposób go precyzyjnie ujmujemy. Podobnie nierówność $x^{2}+y^{2} \leq 9$ opisuje koło o promieniu 3 na płaszczyźnie i nieskończony walec o promieniu podstawy $3 \mathrm{w}$ przestrzeni trójwymiarowej, ale w przestrzeni czterowymiarowej to samo równanie opisuje bryłę, która w dwóch wymiarach jest nieskończona i która nie ma nawet swojej nazwy. Zarówno jednak na płaszczyźnie jak i w przestrzeni czterowymiarowej możemy podać zbiór punktów wspólnych dla obiektów opisanych przez równanie i nierówność. Nasuwa się przypuszczenie (i tylko przypuszczenie), że według Drewnowskiego 1) rozważania formalne nawet tak trudnych pojęć jak dusza czy myśl mogą być prowadzone zrozumiale (choć przekraczają naszą wyobraźnię), 2) opis tak trudnych pojęć można sprowadzić do fenomenów wyobrażalnych, będzie to jednak swoista redukcja, która daje nam wgląd tylko w pewien fragment tego, co badamy (dusza, myśl, inne) - tak, jak wówczas, gdy czterowymiarową bryłę opisaną nierównością $x^{2}+y^{2} \leq 9$ sprowadzamy do figury płaskiej na płaszczyźnie.

„3. Z poprzednich dwóch punktów widoczne jest, jak mogliśmy sobie wyobrażać drogę ścisłego rozwijania teorii metafizycznych jako swoistych interpretacji odpowiednich teorii metageometrii, 
topologii i innych nowoczesnych działów matematyki. Ta analogia formalna $\mathrm{z}$ przestrzennym stosunkiem zawierania się pozwoliłaby na uporządkowanie takich podstawowych pojęć, jak actus - potentia, essentia-existentia, forma-materia, które do dziś dnia pozostawiają bardzo wiele do życzenia pod względem poprawności logicznej. A na nich opiera się wszak cała metafizyka i - pośrednio - cała teologia"6.

Komentarz. Kolejny raz Drewnowski daje wyraz swemu poznawczemu optymizmowi, gdy stwierdza, że odpowiednia interpretacja teorii formalnych daje nadzieję na ścisłe rozwijanie zagadnień metafizycznych, w tym podstawowych pojęć (akt - potencja, istota istnienie itd.). Można postawić pytanie: czy taki optymizm jest uzasadniony? Tekst Drewnowskiego powstał przed II wojną światową, gdy większość przedstawicieli filozofii analitycznej patrzyło nieufnie na problemy metafizyczne. W kolejnych dziesięcioleciach sytuacja uległa jednak zmianie. Do zagadnień filozoficznych (nie tylko metafizycznych) stosowano zarówno narzędzia formalne logiki klasycznej i nieklasycznej, jak i struktury formalne. Przykładowo, rozwój logiki modalnej przyczynił się do pełniejszego zrozumienia konieczności, możliwości przygodności, a więc modalnych aspektów rzeczywistości. Rozwój semantyki dla logik modalnych zaowocował formalnym pojęciem struktury możliwych światów (pojęcie wprowadzone przez Leibniza). Tzw. „STIT - logic” 7 N. Belnapa i innych pozwoliła przyjrzeć się logicznej analizie pojęcia działania (a więc jednej z kategorii Arystotelesa), K. Fine opracował w latach 90. tzw. logikę istoty, w której bada się m.in. problem: co to znaczy, że pewna własność przysługuje przedmiotowi na mocy jego istoty, natomiast B. Wolniewicz w latach 80. sfinalizował teoriokratową interpretację wittgensteinowskiej ontologii stanów rzeczy. Nie powiemy dziś, czy wskazane tu dokonania analityków idą dokładnie w tym kierunku,

6 Tamże, 169.

7 STIT to skrót od angielskiego wyrażenia: sees to it that, co w kontekście podstawowej formuły tej logiki, STIT $(\alpha)$ możemy odczytać jako - „(agent a) powoduje, aby stało się $\alpha$ ”. 
który był zamysłem członków Koła Krakowskiego, ale z pewnością stwierdzić należy: narzędzia i struktury formalne pozwalają na wnikliwą i precyzyjną interpretację podstawowych pojęć i twierdzeń metafizyki.

$\mathrm{Na}$ zakończenie prezentacji niektórych tez Drewnowskiego na temat roli narzędzi i struktur formalnych w filozofii przytoczmy jeszcze punkt 5. oraz fragment jego Dzienników.

„5. Podstawowe dla całej metafizyki i teologii pojęcie analogii samo się poniekąd napraszało w sformułowaniach symbolicznych. Różne bowiem pojęcia, będące interpretacjami tego samego wyrażenia symbolicznego, są analogiczne ze względu właśnie na tę wspólną im strukturę formalno-logiczną. Dalej, same struktury symboliczne mogą wykazywać różne pokrewieństwa, które mogą być podstawą analogii. Św. Tomasz nie miał do rozporządzenia żadnego lepszego przykładu związków formalnych niż proporcja geometryczna: funkcji matematycznych jeszcze wówczas nie znano. Oczywiście więc na proporcji geometrycznej oparł cały swój wykład analogii teologicznej. Było jednak dla nas jasne, że na gruncie nowoczesnych teorii symbolicznych znajdzie się znacznie odpowiedniejsze i subtelniejsze narzędzia formalne na potrzeby analogii teologicznej. Wydawało się nam, iż wystarczy pojęcie stosunków izomorficznych"8.

„Własność zbioru nieskończonego, że jest równej mocy ze swoją częścią właściwą. Ujęcia metafizyczne całościowe są jakimiś takimi odwzorowaniami całej rzeczywistości za pomocą pewnej części tej rzeczywistości. Jak dalece pociąga to zawsze nieskończoność opisywanej rzeczywistości? (...). (por. Nota (6/I - 70), str. 444/5 z 6 stycznia 1970)"9.

8 J.F. Drewnowski, dz. cyt, 170.

9 Tę informację posiadam od ks. P. Adamczyka, który udostępnił mi fragmenty Dziennika prowadzonego przez Drewnowskiego. 
Komentarz. Pojęciem analogii zajmował się w sposób bardziej sformalizowany Bocheński w artykule $O$ analogii z roku $1948^{10}$. Zwróćmy uwagę, że sam Drewnowski wskazuje na pojęcie izomorficzności, które, jego zdaniem, jest bardziej adekwatne dla badania pojęcia analogii niż wykorzystywane przez Tomasza pojęcie proporcji geometrycznej ${ }^{11}$.

Stosunek izomorficzności, o którym tu się wspomina, jest różnie rozumiany (etymologicznie 'izomorfia' to - z greckiego - 'równość kształtów'). Proponuję następujące rozróżnienia. Izomorficzność dwóch struktur gwarantuje:

1. funkcja wzajemnie jednoznaczna między strukturami algebraicznymi, która zachowuje działania;

2. odwzorowanie wzajemnie jednoznaczne między zbiorami (częściowo) uporządkowanymi zachowujące porządek i obiekty wyróżnione (np. maksymalne);

3. homeomorfizm, tj. funkcja wzajemnie jednoznaczna i ciągła „w obie strony”, tj. taka, że zarówno $f$ jak i $f^{-1}$ są funkcjami ciągłymi między uniwersami dwóch przestrzeni topologicznych.

Istotą tak rozumianej izomorficzności jest to, że struktura $S$ izomorficzna do danej $S$, przy pewnym odwzorowaniu, o którym mowa w punktach 1) - 3), jest w pewien sposób „bliźniaczo podobna” do $S$, a to pozwala badać $S$, by wnioskować o $S$. Owo wnioskowanie musi opierać się na określonych warunkach: co jest bowiem podobne z naszego naturalnego punktu widzenia, nie musi być podobne z punktu widzenia owych struktur (dla przykładu, pokazuje się, że bryła przypominająca kubek z uchem jest homeomorficzna z bryłą przypominającą nadmuchaną oponę, tzw. torus). Niżej przedstawię formalnie algebraiczne i topologiczne przykłady stosunku izomorficzności.

10 J. Bocheński, O analogii, w: J. Bocheński, Logika i filozofia. Wybór pism, Warszawa 1993. Oryginalna praca pt. On Analogy publikowana była w The Monist 11(19**)4, 24-447.

$11 \mathrm{~W}$ prywatnej rozmowie prof. P. Błaszczyk przekonywał mnie, że jest nieporozumieniem sądzić iż teoria analogii oparta jest o grecką (euklidesową) teorię proporcji. Sprawę, zapewne, należałoby oddzielnie przemyśleć. 
Nota Drewnowskiego z 6 stycznia 1970 r. również odwołuje się do pewnej „izomorfii”. Przypomnienie definicji zbioru nieskończonego w sensie Dedekinda jest wskazaniem nam drogi, że możemy badać pewne mnogości (zbiory, struktury) ograniczając się do pewnego fragmentu tej mnogości. Czy jest to zasadnicza korzyść? Czy jest to pewna forma rozumowania analogicznego?

\section{FORMALIZM W ONTOLOGII. PODEJŚCIE ALGEBRAICZNE, PODEJŚCIE TOPOLOGICZNE}

Ontologia formalna może być scharakteryzowana jako fragment badań ontologicznych, w których korzysta się z narzędzi formalnych logiki i/lub algebry abstrakcyjnej. Jest więc ontologia formalna obecna od początku współczesnej logiki formalnej (rozważania nad determinizmem i indeterminizmem prowadzone przez Łukasiewicza przy pomocy logiki trójwartościowej można traktować jako fragment badań z zakresu ontologii formalnej). Obecnie autor niniejszego artykułu rozwija fragment ontologii nazywanej ontologią topologiczną - jest to taki rodzaj ontologii (formalnej), w której do interpretowania czy modelowania pojęć i problemów ontologii wykorzystuje się pojęcia i struktury topologiczne (zbiór otwarty, zbiór gęsty, przestrzeń topologiczna, topologiczna przestrzeń dyskretna, homeomorfizm i wiele innych). Poniżej przedstawię pewne pojęcia ontologii opartej na algebrze oraz ontologii topologicznej.

\subsection{PRELIMINARIA FORMALNE}

Niech $\mathbf{K}$ będzie niepustym zbiorem oraz $\vee \mathrm{i} \wedge$ dwoma symbolami oznaczającymi dwuargumentowe operacje supremum i minimum w zbiorze K.

DEFINICJA 1. Trójkę $(\mathbf{K}, \vee, \wedge)$ nazywamy kratą, jeśli dla dowolnych elementów $a, b \in \mathbf{K}$ istnieją $a \vee b \in \mathbf{K}$ oraz $a \wedge b \in \mathbf{K}$. 


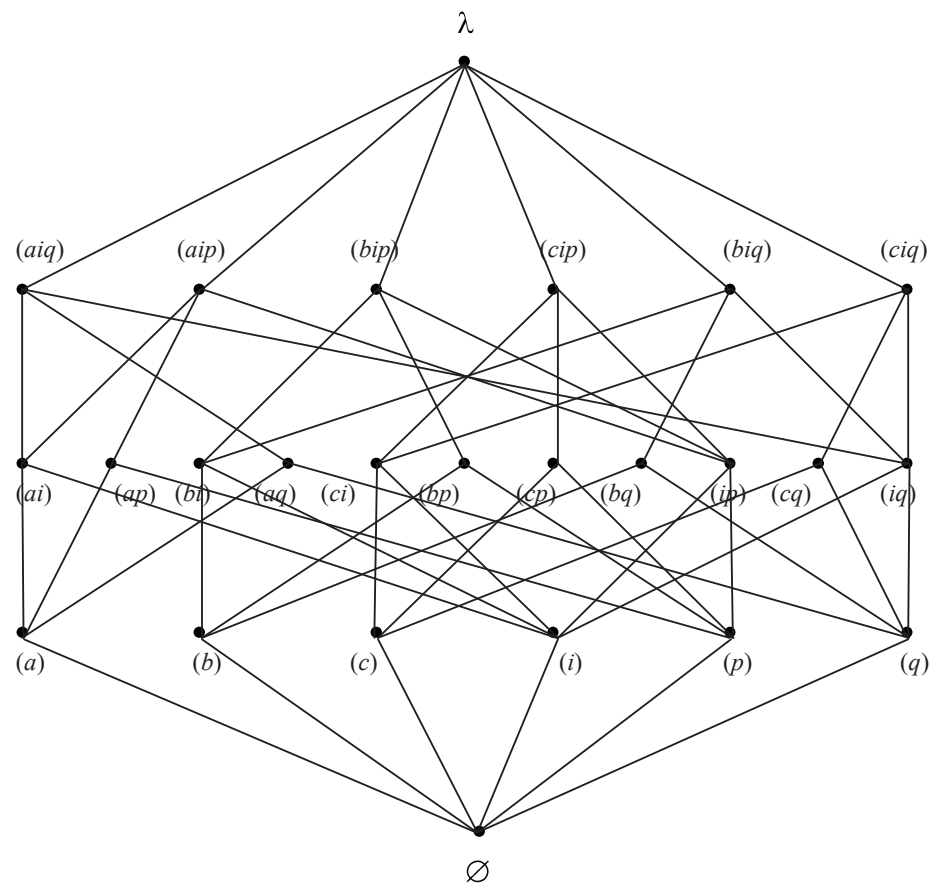

Rys. 1: Krata o sygnaturze $(3,1,2) ; D 1=\{a, b, c\}, D 2=\{i\}, D 3=\{p, q\}$

W latach 80. XX w. Wolniewicz wprowadził pojęcie kraty sytuacji elementarnych. Krata taka jest zdefiniowana aksjomatycznie poprzez minimum 6 aksjomatów; specjalne podklasy klasy takich krat spełniają maksimum 11 aksjomatów. Nie będziemy ich tu przypominać, a wyjaśnimy podstawowe pojęcia za pomocą odpowiedniego diagramu kraty sytuacji elementarnych przedstawionego na Rys. $1^{12}$. Elementami zawsze występującymi w kracie sytuacji elementarnych są $\varnothing$ i $\lambda$. Pierwszy element (zero kraty) to tzw. sytuacja pusta, drugi (jedynka kraty) to tzw. sytuacja niemożliwa. Elementy występujące na diagramie bezpośrednio nad $\varnothing$ nazywane są atomami kraty.

12 Czytelnik zainteresowany aksjomatyką znajdzie ją m.in. w: B. Wolniewicz, Logic and Metaphysics. Studies in Wittgenstein's Ontology of Facts, Warszawa 1999. 
Za pomocą odpowiednio zdefiniowanej relacji równoważności są one podzielone na podzbiory, z których każdy nazywany jest wymiarem kraty. Diagram przedstawia kratę $z$ trzema wymiarami: jeden wymiar złożony z elementów $a, b, c$, drugi z jednego elementu $i$ oraz trzeci z dwóch elementów $p$ i $q$. W takim przypadku mówimy, że krata ma sygnaturę $(3,1,2)$. Wspomniana wyżej relacja równoważności „skupia" w danym wymiarze takie atomy, że jeśli dowolne dwa są różne, to ich kres górny jest równy $\lambda$ (kres dolny jest oczywiście równy $\varnothing$ dla dowolnych dwóch różnych atomów). $Z$ kolei elementy występujące bezpośrednio pod $\lambda$ to tzw. maksymalne sytuacje elementarne zwane możliwymi światami. Zbiór wszystkich możliwych światów w kracie Wolniewicz nazywa przestrzenią logiczną.

Powyższa krata służyć może do analizy fragmentu ontologii egzystencjalnej Ingardena. Litery w kracie oznaczają kolejno następujące momenty bytowe: $i-$ przedmiot jest samoistny, $a$ - przedmiot jest niesamodzielny, $b$ - przedmiot jest zależny, $c$ - przedmiot jest niezależny, $p$-przedmiot jest pierwotny, $q$ - przedmiot jest pochodny. Momenty bytowe traktujemy tu zatem jak elementarne sytuacje (Wolniewicz) lub proste (atomowe) i złożone stany rzeczy (Wittgenstein). Krata ujmuje pewne możliwe stany rzeczy w obrębie przedmiotów samoistnych (połączyliśmy tu analizy fenomenologiczno-ontologiczne Ingardena $\mathrm{z}$ analizami ontologiczno-algebraicznymi filozofów analitycznych). Dla przykładu możliwy świat (bip) opisuje przedmiot samoistny, zależny i pierwotny - jako pewną logiczno-ontologiczną możliwość.

Mając operacje kresu górnego (maksimum) i kresu dolnego (minimum) łatwo, jak wiemy, można zdefiniować porządek (częściowy) $\leq \mathrm{w}$ kracie:

DEFINICJA 2. Dla dowolnych $x, y(x \leq y \mathrm{wtw} x \wedge y=x \mathrm{wtw} x \vee y=y)$.

Wprowadźmy teraz pewne pojęcia topologiczne. Okaże się, że topologiczne ujęcie mnogości sytuacji jest ogólniejsze od podejścia teoriokratowego. 
DEFINICJA 3. Przestrzenią topologiczną nazywamy dowolną parę $(X, \boldsymbol{T}(X))$, gdzie $X$ jest dowolnym zbiorem, a $\boldsymbol{T}(X)$ jest rodziną podzbiorów zbioru $X$ spełniających następujące warunki:

1. $\varnothing \mathrm{i} X$ należą do $T(\mathrm{X})$,

2. dowolna suma zbiorów z $\boldsymbol{T}(X)$ jest elementem $\boldsymbol{T}(X)$,

3. skończony iloczyn zbiorów z $\boldsymbol{T}(X)$ jest elementem $\boldsymbol{T}(X)$.

(Rodzinę $\boldsymbol{T}(X)$ nazywamy czasem krótko topologią).

DEFINICJA 4. Niech $A \subset X$. Wówczas dowolna parę $(A, \boldsymbol{T}(A))$ taką, że dla dowolnego $B$, jeśli $B=A \cap C$, dla $C \in \boldsymbol{T}(X)$, to $\mathrm{B}$ jest elementem $\boldsymbol{T}(A)$, nazywamy podprzestrzenią przestrzeni $(X, \boldsymbol{T}(X))$.

W topologii ogólnej definiuje się pojęcie bazy dla danej przestrzeni topologicznej.

DEFINICJA 5. Mówimy, że rodzina $\boldsymbol{B}$ zbiorów jest bazą dla przestrzeni topologicznej $(X, \boldsymbol{T}(X))$, jeśli każdy zbiór z $\boldsymbol{T}(X)$ da się przedstawić jako suma (skończona bądź nieskończona) zbiorów z $\boldsymbol{B}$.

Powyższe definicje zilustrować można następującymi przykładami.

(P1). Niech $X$ będzie dowolnym zbiorem oraz $2^{X}$ rodziną wszystkich jego podzbiorów. Wówczas $\left(X, 2^{X}\right)$ jest przestrzenią topologiczną nazywaną przestrzenią dyskretną. $Z$ kolei para $(X,\{\varnothing, X\})$ jest nazywana przestrzenią antydyskretną bądź trywialną.

(P2). Najlepiej znaną przestrzenią topologiczną jest tzw. euklidesowa bądź naturalna przestrzeń topologiczna. Wówczas $X=\boldsymbol{R}$ (zbiór liczb rzeczywistych) a $\boldsymbol{T}(\boldsymbol{R})$ składa się z takich zbiorów, które są dowolnymi sumami przedziałów $(q i, q j$ ), dla $q \in Q$ (zbiór liczb wymiernych).

(P3). Rodzina wszystkich przedziałów $\left(q_{i}, q_{j}\right)$, dla $q_{i}<q_{j}, q \in Q$, jest bazą przestrzeni naturalnej. Dla przestrzeni topologicznej $(X, T(X))$, gdzie $X=\{1,2,3,4,5,6\}$ oraz

$\boldsymbol{T}(X)=\{\varnothing,\{1,2,3,4,5,6\},\{1,2,3\},\{2,3,4\},\{3,4,5,6\},\{2,3\},\{3\}$, $\{3,4\},\{1,2,3,4\},\{2,3,4,5,6\}\}$

bazą jest rodzina: $\{\{1,2,3\},\{2,3,4\},\{3,4,5,6\},\{2,3\},\{3\},\{3,4\}\}$ $\cup\{\varnothing\}$. 
(P4) Ponieważ będziemy porównywali podejście teoriokratowe i topologiczne zauważmy, że elementy przedstawionej właśnie rodziny $\boldsymbol{T}(X)$ tworzą kratę, której diagram przedstawić możemy jak na RYS. 2. Kresem górnym dwóch dowolnych elementów z kraty jest ich suma (mnogościowa), natomiast kresem dolnym jest ich iloczyn.

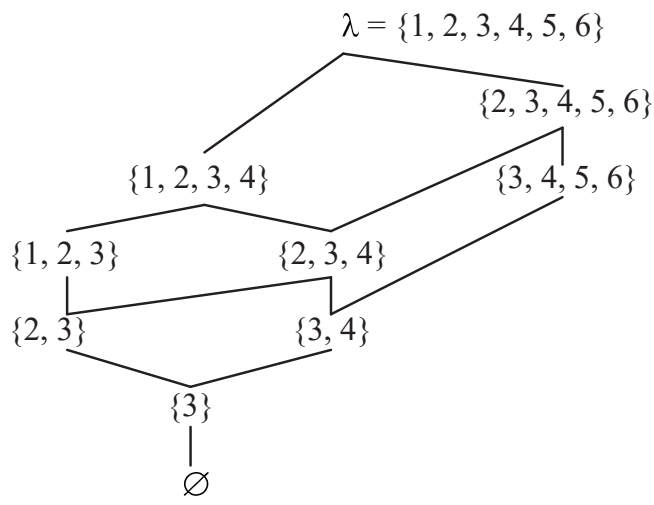

Rys. 2: Przestrzeń topologiczna jako krata

W końcowej części punktu 1 tej pracy przypomniałem w sposób ogólny różne pojęcia „stosunku izomorficzności”, który dla Drewnowskiego i członków Koła miał być odpowiednikiem pojęcia analogii wykorzystywanego przez scholastyków. Przypomnijmy więc podstawowe określenia ,izomorfii”.

DEFINICJA 6. Niech $\left(A_{1}, \#\right)$ oraz $\left(A_{2},{ }^{*}\right)$ będą dwoma strukturami algebraicznymi, tj. parami złożonymi z pewnego zbioru i działaniami n-argumentowymi w tych zbiorach. Dla ustalenia uwagi przyjmijmy, że \# $\mathrm{i}$ * są działaniami dwuargumentowymi. Wówczas dowolna różnowartościowa i na funkcja $h \mathrm{z} A_{1}$ w $A_{2}$ jest nazywana izomorfizmem, jeśli dla dowolnych $a_{1}, b_{1} \in A_{1}$ spełniony jest warunek: $h\left(a_{1} \# b_{1}\right)=h\left(a_{1}\right) * h\left(b_{1}\right)$. Zwykle mówi się wówczas, że struktury $\left(A_{1}, \#\right)$ oraz $\left(A_{2},{ }^{*}\right)$ są izomorficzne. 
Uwaga. Struktury algebraiczne mogą być wyposażone w większą ilość działań np. $\#_{1}, \ldots, \#_{\mathrm{n}} \mathrm{i}{ }_{1}{ }_{1}, \ldots,{ }_{\mathrm{n}}$. Wówczas wymaga się aby spełnione były warunki:

$h\left(a_{1} \#_{i} b_{1}\right)=h\left(a_{1}\right){ }_{i} b\left(b_{1}\right)$, dla dowolnego $i, 1 \leq i \leq n$.

DEFINICJA 7. Niech $\left(A_{1}, \leq_{1}\right)$ oraz $\left(A_{2}, \leq_{2}\right)$ będą dwoma zbiorami (częściowo) uporządkowanymi. Mówimy, że struktury te (zbiory) są izomorficzne, jeśli istnieje odwzorowanie $h \mathrm{z} A_{1} \mathrm{w} A_{2}$ różnowartościowe i na takie, że:

$a_{1} \leq_{1} b_{1}$ wtw $h\left(a_{1}\right) \leq_{2} h\left(b_{1}\right)$.

Uwaga. Niekiedy nadaje się dodatkowe warunki, by odwzorowanie $h$ przekształcało elementy charakterystyczne pierwszego zbioru na elementy charakterystyczne drugiego (np. jedynkę w jedynkę, a elementy maksymalne na maksymalne).

DEFINICJA 8. Dla danych dwóch przestrzeni topologicznych $\left(X_{1}, \boldsymbol{T}\left(X_{1}\right)\right)$ i $\left(X_{2}, \boldsymbol{T}\left(X_{2}\right)\right)$ określamy: homeomorfizmem jednej przestrzeni w drugą nazywamy dowolną funkcje

$f: X_{1} \rightarrow X_{2}$ taką, że

a) fjest wzajemnie jednoznaczna (tj. różnowartościowa i na),

b) zarówno $f$ jak i $f^{-1}$ są funkcjami ciągłymi.

Uwaga. W topologii ogólnej funkcję ciągłą definiujemy ogólniej niż w standardowej matematyce szkolnej. Dowolna funkcja $f \mathrm{z} A$ do $B$ jest ciągła w punkcie $x_{0}$ przestrzeni $A$ (przy określonych przestrzeniach topologicznych zadanych na $A$ i $B$ ) wtedy i tylko wtedy, gdy dla dowolnego otoczenia $C$ punktu $f\left(x_{0}\right)$ z $\boldsymbol{T}(B)$ istnieje otoczenie $D$ punktu $x_{0}$ z $\boldsymbol{T}(A)$ takie, że $f(D) \subset C$. Jeśli funkcja jest ciągła w każdym punkcie swojej dziedziny, to mówimy, że jest ciągła.

\subsection{FORMALNE PODEJŚCIE DO PROGRAMU KOŁA KRAKOWSKIEGO W UJĘCIU DREWNOWSKIEGO}

Jesteśmy teraz przygotowani do podania stosownych przykładów, które zilustrują zarówno pewne problemy ontologiczne jak i niektóre 
zamierzenia Drewnowskiego i pozostałych członków Koła. Tych kwestii jest niemało, wypunktujemy zatem tylko kilka z nich.

Rozpocznijmy od dwóch problemów.

1. Czy można mieć nadzieję, że zastosowanie narzędzi formalnych, które pojawiły się w nowoczesnej matematyce i logice, daje nowe możliwości poznawcze w filozofii i bardziej „czuły” wgląd w (co najmniej niektóre) problemy filozoficzne? Drewnowski odpowiadał na to pytanie pozytywnie.

2. Czy pojęcia izomorfii zaproponowane przez matematyków sprzyjają wnikliwszym analizom (per analogiam)? Tu ponownie, przypomnijmy, Drewnowski był optymistą. Czy zasadnie?

W pracy Ontology in Tractatus Logico-Philosophicus. A Topological Approach ${ }^{13}$ wprowadziłem pewne uogólnienie kraty Wolniewicza. Mianowicie, odrzuciłem aksjomat Wolniewicza mówiący o skończonej liczbie wymiarów. Przyjmuję więc, że mamy przeliczalną liczbę wymiarów $D_{1}, D_{2}, \ldots$, gdzie każdy wymiar $D_{i}$ składa się ze skończonej bądź przeliczalnej ilości atomów postaci $\left\{d_{i j}\right\}$. Wymiar $D_{i}$ można zatem zdefiniować jako: $D_{i}=\left\{\left\{d_{i 1}\right\},\left\{d_{i 2}\right\}, \ldots\right\}$. Ponieważ elementy w wymiarze są zbiorami (jedno - elementowymi), to można potraktować rodzinę, która zawiera po jednym zbiorze z każdego wymiaru, jako bazę dla utworzenia topologii (przestrzeni topologicznej). Topologię, której dowolny zbiór jest sumą (skończonej lub przeliczalnej ilości) elementów z bazy nazywam (zdefiniowałem to w Kaczmarek [2019b]) topologią Wittgensteina. Okazuje się, że możemy tworzyć różne takie rodziny, które zawierają po jednym elemencie $\mathrm{z}$ każdego z tych wymiarów (czyli różne bazy). Suma wszystkich topologii, które są generowane przez owe bazy, wraz z elementem

13 J. Kaczmarek, Ontology in Tractatus Logico-Philosophicus. A Topological Approach, w: Philosophy of Logic and Mathematics, Proceedings of the 41st International Ludwig Wittgenstein Symposium, red. G.M. Mras, P. Weingartner, B. Ritter, De Gruyter, Berlin 2019, 246-262. 
wyróżnionym $\lambda$ dają strukturę, która jest kratą. Kres górny i dolny zadane są tu warunkami podanymi w następującej definicji:

DEFINICJA 9. Niech $\left(X, \boldsymbol{T}_{X}\right)$ będzie dowolną przestrzenią topologiczną, $A_{1}, A_{2}, \ldots$, dowolnymi podzbiorami $X$ takimi, że dla dowolnych $i, j A_{i} \not \subset A_{j}$ i $A_{j} \not \subset A_{i}$ i dla dowolnego $k \in \omega\left(A_{k}, T_{A k}\right)$ jest podprzestrzenią topologiczną przestrzeni $\left(X, \boldsymbol{T}_{X}\right)$. Wówczas rodzinę $G W L=\left\{\mathrm{S}: \mathrm{S} \in T_{A K}\right.$ dla pewnego $\left.k \in \omega\right\} \cup\{\lambda\}$ z operacjami $\cup$ jako kresem górnym, $\subseteq$ jako kresem dolnym oraz $\varnothing$ (zero) i $\lambda=X$ (jedynka) jako najmniejszym i największym elementem $G W L$ nazywamy uogólnioną kratą Wittgensteina, w której:

$$
S_{i} \cup S_{j}=\left\{\begin{array}{c}
S_{i} \cup S_{j}, \text { jeśli } S_{i} \cup S_{j} \in T_{A_{k}}, \text { dla pewnego } k \in \omega \\
\lambda, \text { w przeciwnym wypadku. }
\end{array} ;\right.
$$

$$
S_{i} \cap S_{j}=\left\{\begin{array}{c}
S_{i} \cap S_{j}, \text { jeśli } S_{i} \cap S_{j} \in T_{A_{k}}, \text { dla pewnego } k \in \omega \\
\varnothing, \text { w przeciwnym wypadku. }
\end{array} ;\right.
$$

Można teraz podać następujące twierdzenia.

Twierdzenie 1. Każda topologia Wittgensteina jest topologią dyskretną.

Twierdzenie 2. Dowolna topologia Wittgensteina jest izomorficzna $z$ dowolną topologią ( $w$ tym ze swoją podprzestrzenią), generowaną przez bazę przeliczalną (określoną wyżej). Inaczej, w uogólnionej kracie Wittgensteina wszystkie topologie z bazą przeliczalną złożoną ze zbiorów jednoelementowych są izomorficzne.

Twierdzenie 3. Co więcej, dowolne dwie topologie o bazie przeliczalnej złożonej ze zbiorów jednoelementowych są homeomorficzne.

Dowody powyższych twierdzeń są oczywiste. Podajmy jednak uzasadnienie (dowód) dla twierdzenia trzeciego.

Dowód. Istotnie, rozważmy dwie różne przeliczalne bazy $\boldsymbol{B}_{1}$, $\boldsymbol{B}_{2}$ złożone ze zbiorów jednoelementowych. Każda z nich generuje przestrzeń topologiczną odpowiednio $\boldsymbol{T}_{1}$ i $\boldsymbol{T}_{2}$ taką, że dowolny element z topologii $\boldsymbol{T}_{\mathrm{i}}$ jest sumą pewnej liczby zbiorów z bazy $\boldsymbol{B}_{\mathrm{i}}$, 
dla $i=1$, 2. Ponieważ bazy są przeliczalne, więc istnieje odwzorowanie $f$ różnowartościowe i na przekształcające elementy jednej bazy na elementy drugiej. Rozszerzamy tę funkcję na wszystkie elementy z danej topologii następująco: niech $A \in \boldsymbol{T}_{1}$; wówczas $A$ jest sumą skończoną bądź nieskończoną elementów z $\boldsymbol{B}_{1}$; Oznaczmy ją $\bigcup_{k}\left\{\mathrm{a}_{k}\right\}$; połóżmy $h(A)=\bigcup_{k} f\left(\left\{\mathrm{a}_{k}\right\}\right)$; odwzorowanie $h$ jest różnowartościowe i na, i przekształca przestrzeń topologiczną $T_{1}$ na $T_{2}$; ponieważ dowolne odwzorowanie $z$ przestrzeni dyskretnej jest ciągłe, a obie topologie są dyskretne, zatem zarówno $h$ jak i $b^{-1}$ są ciągłe, a to znaczy, $\dot{z}$ e $h$ jest homeomorfizmem.

Jeśli Drewnowski myślał o tego rodzaju izomorficzności, to możemy powiedzieć, że, istotnie, jego przewidywania były zasadne: możemy badać pewną strukturę (pewien byt), za pomocą fragmentu tej struktury. Zauważmy jednak, że - niestety - zarówno obiekt wyjściowy, jak i obiekt izomorficzny, który badamy, jest nieskończony. Wydaje się zaś, że mamy skłonność do myślenia o rzeczach nieskończonych przy pomocy rzeczy (narzędzi) skończonych. Tutaj tego nie uzyskamy.

Twierdzenie 4. Niech dana będzie krata Wolniewicza $(\boldsymbol{W}, \leq)$ oraz $w$ niech będzie dowolnym możliwym światem. Oczywiście zbiór wszystkich sytuacji $s$ takich, że $s \leq w$, jest tzw. właściwym ideałem maksymalnym. Dowolne dwa tak wyznaczone ideały są izomorficzne.

Dowód. Ponieważ krata Wolniewicza ma skończoną ilość wymiarów, więc dla danego świata w istnieje skończona ilość $k$ atomów (po jednym z każdego wymiaru) takich, że ich kres górny jest tym $w$. Podobnie dla dowolnego innego świata w'. Ponieważ każdy możliwy świat jest kresem górnym $k$ atomów, więc możemy zbudować odpowiedni izomorfizm jak w dowodzie twierdzenia 3.

Wniosek filozoficzny jest następujący. Ze względu na twierdzenie powyższe wystarczy zbadać jeden ideał w kracie, aby znać związki strukturalne wszystkich innych ideałów (nawet jeśli jest ich nieskończenie wiele; pamiętamy bowiem, że choć w kracie Wolniewicza wymiarów jest skończona ilość, to atomów w danym wymiarze może 
być nieskończenie wiele) ${ }^{14}$. Korzyść uzyskana dzięki formalizmowi jest zatem oczywista.

Czy izomorfizm bądź homeomorfizm wyjaśnia związki podawane przez stosunki analogiczne? Oto $\mathrm{w}$ analizach filozoficznych podaje się np. następujące przykłady takich stosunków:

(1) Człowiek tak się ma do swego istnienia, jak zwierzę do swego istnienia.

(2) Człowiek tak się ma do swego poznania, jak zwierzę do swego ${ }^{15}$.

Nie mam jednoznacznej odpowiedzi na postawiony problem, a intuicja podpowiada, że w podanych przykładach stosunków chodzić może o kwestię bardziej „delikatną" niż formalnie rozumiana proporcja bądź izomorfizm na poziomie struktur. Być może też należy szukać innych, formalnych analogii np.:

(3) Możliwy świat $w$ tak się ma do elementów ideału wyznaczonego przez w, jak możliwy świat w' do elementów ideału wyznaczonego przez $w$.

Wówczas powiedzieć możemy, że relacje, które wiążą świat $w$ z elementami jego ideału, są takie same jak relacje między światem w' a elementami ideału wyznaczonego przez $w^{\prime 16}$. Pozostawiam tę kwestię do dalszego badania.

Mam nadzieję, że przedstawione tu rozważania formalne pokazują, że przy użyciu narzędzi formalnych można - jak sugerował i postulował Drewnowski - mówić w sposób zrozumiały, dorzeczny,

14 Przeprowadziłem pewne analizy krat sytuacji, w których dopuszcza się topologie nieposiadające atomów (tzw. hybrydowe kraty sytuacji elementarnych). W takim przypadku analogon twierdzenia 4 nie jest prawdziwy.

15 Por. Z. Wolak, Analogia w filozofii i nauce, Zagadnienia Filozoficzne w Nauce 30(2002), 89-111.

16 Co ciekawe, mimo, że twierdzenie 4 nie zachodzi w kratach z topologiami bez atomów (por. przypis 13), to stosunek (3) nadal jest zasadny. Nie przedstawiłem dokładnie hybrydowych krat sytuacji, ale da się pokazać, że pewne relacje na strukturach nieskończonych są takie same jak w skończonych. 
precyzyjny (z określonymi pojęciami), sensowny i niesprzeczny ${ }^{17}$ o problemach filozoficznych. Badaczy prowadzących swoje dociekania z użyciem narzędzi formalnych nie trzeba przekonywać do takiej metody. Z kolei badaczy (zarówno filozofów jak i przedstawicieli nauk szczegółowych) pomijających metody formalne przekonają może następujące rezultaty.

1) W pracy Hermeneutyka logiczna Wolniewicz przedstawia autorską metodę nazywaną hermeneutyką logiczną. Jest to metoda pozwalająca na translację pewnych twierdzeń filozoficznych (pochodzących z różnych kierunków czy doktryn filozoficznych) na twierdzenia formalne pewnej struktury formalnej. Translacje tych twierdzeń możemy wówczas porównywać w danej strukturze. Wolniewicz pokazał, że dwa twierdzenia:

(H) (Twierdzenie Hume’a). Cokolwiek jest różne, jest też rozłączalne,

(W) (Twierdzenie Wittgensteina). Jedno może być faktem lub nie, a wszystko inne pozostawać takie samo,

są równoważne, gdy oba twierdzenia przekształcimy na twierdzenia formalne teorii sytuacji elementarnych. Zauważmy: twierdzenie Hume’a dotyczy pewnych zależności między obiektami mentalnymi, twierdzenie Wittgensteina - zależności między obiektami ontycznymi. Jest jednak między obu twierdzeniami ustalona (ścisła) zależność.

2) Przyjrzyjmy się dokładniej, jakie jest znaczenie tezy Wittgensteina: Jedno może być faktem lub nie, a wszystko inne pozostawać takie samo ${ }^{18}$. Wolniewicz proponuje następującą tezę formalną:

17 Posłużyłem się tu określeniami, które wymienia Drewnowski w punkcie 1 swojej pracy (por. część pierwszą niniejszego artykułu).

18 W Traktacie Wittgensteina podane są następujące tezy: 1.2 The world divides into facts. 1.21 Any one can either be the case or not be the case, and everything else remain the same. Komentuję tu jedynie tezę $\mathbf{1 . 2 1}$ (która w zamyśle Wittgensteina jest wyjaśnieniem tezy 1.2). 
(2) $\forall x \forall w\left(x \neq \varnothing \wedge w \in S P \rightarrow\left(x \leq w \rightarrow \exists w^{\prime} \in S P\left(\neg x \leq w^{\prime} \wedge d(x, w) \leq w^{\prime}\right)\right)\right)$,

czyli - jak wyjaśnia Wolniewicz - w stylizacji języka naturalnego: ,jeżeli dana niepusta sytuacja elementarna $x$ zachodzi w jakimś możliwym świecie $w$, to jest też taki świat możliwy w', w którym sytuacja ta nie zachodzi, a zachodzi całe jej dopełnienie do świata w"19. Wyjaśnijmy, że dopełnienie sytuacji $x$ zachodzącej w świecie $w$ to taka sytuacja $y$, że kres górny $x$ i $y$ to świat wa kres dolny to sytuacja pusta. W kracie na RYS. 1 dopełnieniem sytuacji (a) w świecie(aiq) jest element $(i q)$. Dzięki formalizmowi otrzymujemy zatem ścisłą interpretację tezy wyrażonej w języku naturalnym (języku Traktatu Wittgensteina). Sądzę, że o tak uprawianą filozofię postulowali Drewnowski i pozostali członkowie Koła Krakowskiego.

\section{BIBLIOGRAFIA}

Adamczyk M., Wiedza - Wiara. Racjonalnośc. Jana Franciszka Drewnowskiego program logizujacej modernizacji myśli filozoficzno-teologicznej, TN KUL JP II, Lublin 2015.

Bocheński J., O analogii, w: J. Bocheński, Logika i filozofia. Wybór pism, Wydawnictwo Naukowe PWN, Warszawa 1993, 50-78.

Drewnowski J.F., U progu nowoczesnej syntezy filozoficznej, Znak 10(1958)53, 1228-1303.

Drewnowski J.F., Filozofia i precyzja. Zarys programu filozoficznego i inne, red. S. Majdański, S. Zalewski, TN KUL, Lublin 1996.

Kaczmarek J., Atom ontologiczny: atom substancji, Przegląd Filozoficzny. Nowa Seria 25(2016)4(100), 131-145.

Kaczmarek J., On the Topological Modelling of Ontological Objects: Substance in the Monadology, w: Polish Contemporary Ontology, red. B. Skowron, De Gruyter, Berlin 2019, 149 - 159

Kaczmarek J., Ontology in Tractatus Logico-Philosophicus. A Topological Approach, w: Philosophy of Logic and Mathematics, Proceedings of the 41st International Ludwig Wittgenstein Symposium, red. G.M. Mras, P. Weingartner, B. Ritter, De Gruyter, Berlin 2019, 246-262.

19 B. Wolniewicz, Hermeneutyka logiczna, w: tenże, Filozofia i wartości, Warszawa 1998, $24-43$. 
Wittgenstein L., Tractatus logico-philosophicus, tłum. z niem i wstęp B. Wolniewicz, BKF, PWN, Warszawa 1997.

Wolak Z., Analogia w flozofii i nauce, Zagadnienia Filozoficzne w Nauce 30(2002), 89-111.

Wolak Z., Naukowa filozofia Kota Krakowskiego, Zagadnienia Filozoficzne w Nauce 36(2005), 97-122

Wolniewicz B., A formal ontology of situations, Studia Logica 41(1982)4, 381-413.

Wolniewicz B., Hermeneutyka logiczna, w: tenże, Filozofia i wartości, Wydział Filozofii i Socjologii UW, Warszawa 1998, 24-43.

Wolniewicz B., Logic and Metaphysics. Studies in Wittgenstein'sOntology of Facts, Polskie Towarzystwo Semiotyczne, Warszawa 1999.

\title{
ON THE USE OF FORMAL TOOLS AND STRUCTURES IN PHILOSOPHY. FORMAL ONTOLOGY AND TOPOLOGICAL ONTOLOGY
}

\begin{abstract}
According to Aristotle, logic is a tool for philosophy. After nearly two and a half thousand years, we can say that not only logic, but also other formal tools and structures (algebra, topology, branched proof, induction) are tools for philosophical and also scientific consideration. Jan F. Drewnowski supported the use of formal tools in philosophy.

In this article I describe Drewnowski's position in relation to the formal study of philosophical problems (using logic and mathematical concepts). I also present contemporary formal solutions to certain philosophical problems, which can be understood as a justification for Drewnowski's anticipation of the „power of formalism” and which in his time -were not always well received.
\end{abstract}

Keywords: formal philosophical tools, formal structures, philosophical program of the Krakow Circle, formal ontology, topological ontology

\footnotetext{
JANUSZ KACZMAREK

kaczmarek@filozof.uni.lodz.pl

Uniwersytet Łódzki, Instytut Filozofii, Katedra Logiki i Metodologii Nauk

Kopcińskiego 16/18, 90-232 Łódź
}

DOI: 10.21697/spch.2019.55.2.05 